\title{
Analysing the Sustainability Challenges of Informal Urban Settlements: The Case of Chibolya in Lusaka Zambia
}

\author{
Jonathan Simbeya Mwamba ${ }^{1}$ \\ ${ }^{1}$ College of Architecture and Urban Planning, Tongji University, Shanghai, China \\ Correspondence: Jonathan Simbeya Mwamba, College of Architecture and Urban Planning, Tongji University, \\ Siping Road, Shanghai, China. E-mail: jsmarchitect@gmail.com
}

Received: August 5, 2020

doi:10.5539/jsd.v13n6p55
Accepted: October 12, 2020

Online Published: October 18, 2020

URL: https://doi.org/10.5539/jsd.v13n6p55

\begin{abstract}
Presently, informal settlements exist as part of the urban fabric and a major constituent of the residential geographies of most Cities in Sub-Saharan Africa. The growth of informal settlements in cities of the global south has been widely discussed in existing literature as a critical concern. Urban development literature in Zambia in particular has focused on the rapid urbanization and poverty growth, but barely explains how this affects settlement sustainability. Studies have focused on measures put in place by government and supporting organisations to help find solutions to the problem. But this has been done without providing specifics as relates to interventions for settlement sustainability and user perceptions of their living environments. The article provides a conceptual analysis of the local dynamics influencing informal settlement development and sustainability. The historical perspective and modern day realities of informal urban settlement settings in Lusaka in Zambia are also reviewed. The case study findings indicate a need to refocus development interventions in informal settlements by considering informal dwellers concerns and requirements when formulating settlements development strategies. The article offers an insight into sustainability challenges that the settlement population faces despite a variety of development interventions by the State and private agencies. The article shows the potential success and sustainability of interventions when informal settlement residents are empowered and take responsibility of their own development agenda. The paper points out the need for collaborative approach to informal settlement improvement where all stakeholders including the local residents, participate in all stages of settlement development.
\end{abstract}

Keywords: informal urban settlements, urban informality, environmental quality analysis

\section{Introduction}

Urban informality has become an integral component to the functioning of cities of the Global South. Informality remains the only livelihood options for the majority of the urban poor and marginalised as the formal sectors buckle under the strain of the rapidly growing urban populations and their accompanying demands. UN-Habitat (2008) estimates the informal settlement population to be well over 800 million in the global south. Solutions to the challenge of informal urban settlements have ranged from demolition to upgrading and redevelopment over the last 60 years. Zambia like many other developing countries faces housing and urban development challenges. The country has developed against the backdrop of a colonial legacy of segregated housing, high rate of urbanisation, high population growth rate and poor economic growth with the resultant effects of inadequate and unaffordable housing options for the urban poor. This has resulted in the illegal occupation of land and growth of unregulated informal settlements. Government indifference and lack of supporting infrastructure to encourage efficient urban planning has led the urban poor to devise solutions to their housing challenges. The growth of informal urban settlements has been in tandem with rapid urbanisation.

This study aims to provide insight in to the urban challenges facing informal urban settlement residents of Chibolya. The study observes that despite the high informality, residents opt to stay in the settlement as it stands as a gateway to opportunities in the formal environment. The explanatory theory of Environment-Behaviour Relations (EBR) shows that the informal built environment is filtered by local cultural factors. As such informal settlement built form has to be understood within its context. Settlement interventions need to take into consideration local sociocultural, spatial and economic dynamics in order to formulate sustainable solutions to the challenge posed by informality. This paper is based on the case study research carried out in Chibolya informal urban settlement in 
Lusaka city, Zambia. Empirical results are presented which indicate that despite the state of informality respondents choose to live in the settlement because of the livelihood opportunities it offers to the urban poor. Tenure security provision encourages improved investment in housing by landlords. The efforts of NGOs and other private actors working in collaboration with the community foster more resilient solutions to the settlements problems. The study highlights potential achievements when informal communities are given responsibility to manage their development according to their local needs, with sufficient guidance. It proposes that future interventions need to be local influenced and driven for them to be embraced and appreciated. The final section dedicates itself to discussing the results, limitations, and future lines of inquiry.

\section{Literature Review}

\subsection{Urban Informality}

In the developing world, informality is all encompassing and manifests beyond the settlement level. Urban informality provides a window into understanding state poverty and inequality (Mukhija and Loukaitou-Sideris, 2015) and involves the activities occurring beyond state control (Dovey \& King, 2012). McFarlane and Waibel (2012, p. 2), observes that where the state is unable to provide formal regulation people create informal institutions to coordinate social interaction in times of rapid socio-economic or urban growth. De Soto (2000) observes that the urban poor engage in the informal sector as a survival and coping mechanism. By default they have to function outside the realm of formality in order to earn a living. The urban informality offers a means of bypassing crippling regulations of the formal economy and tolerated in avoidance of social unrest among the urban poor and marginalised. There is growing awareness that urban studies need to be sensitive to the growing challenge of urban informality in cities of the global South (Neuwirth, 2012; Dovey \& King, 2012; Roy, 2009; Roy \& AlSayyad, 2004). Research shows that informality exist in every country and informality to the urban poor represents an asset for managing their state of deprivation and a means of circumventing the state laws, taxes and regulation (Dovey, 2013; Neuwirth, 2012; Portes, Castells, and Benton 1989).

A vivid physical manifestation of the phenomena of informality is the proliferation of informal settlements (de Soto, 1989). Informal settlements are now commonly considered as centres of ingenuity and creativity than dens of deprivation (Roy, 2011). Improving the lives of informal settlement residents remains one of the cardinal development challenges of the 21 st century (Fox, 2014). Studies on urban informality have shown how informal settlements have the potential to be much more than just an affordable source of housing for the urban poor (De Soto, 1989). However the lack of knowledge and comprehension of urban informality has often led to poor management of the slum challenge (Dovey and King, 2011). Manifestations of urban informality have mostly remained invisible on official maps and from the view of the formal city (Kamalipour \& Dovey, 2019). The term 'informal' refers to both the practice and territorial formation. However there are a myriad of urban morphologies and socio-spatial conditions representing the various existing forms of urban informality (McFarlane, 2012; Dovey and Kamalipour 2018).

There are currently are a number of planning approaches to the challenge of urban informality. Mukhija and Loukaitou-Sideris (2015) offers four broad perspectives and remedies to informality. Bernhardt et al. (2008) and Portes, Castells, and Benton (1989) attribute weak state regulation and international expansion of capitalism for the rise in informality and argue for improved laws and regulation enforcement to stem the rise in informality. While de Soto (1989) submits that state over-regulation and the resulting unrealistic benchmarks lead the urban poor to seek refuge in informality as an escape from the restrictive formal economy. He advocates for deregulation to ease the urban poor's passage into the formal economy. Informality is also regarded as an inevitable structural phenomenon which requires concerted state and civil society engagement to normalise or eliminate (Iskander and Lowe 2010). Payne (2001) proposes regularisation by guarantees against eviction, provision of infrastructure and incremental upgrading as a solution. Ananya Roy has a sceptical view of the state's arbitral use of its regulatory powers to label various sectors as informal without considering the economic benefits such sectors may offer (Roy 2005, 2009).

\subsection{Informal Urban Settlements}

The terms informal settlement and slum are nearly comparable in meaning and used interchangeably in planning literature in sub-Saharan Africa and Zambia in particular (Richmond, Myers \& Namuli, 2018). An informal urban settlement is a consolidated area of the city with limited access to urban services characterised by poor living conditions, spontaneous built environment and generally composed of a population with low socio- economic means (Cronin, 2012). Rapid urban growth without sufficient urban infrastructure development has resulted in a high proportion of informal settlements (UN-Habitat 2008). These communities are typified by poor access to safe water, sanitation, low quality of housing, overcrowding and insecure tenure status (UN Habitat, 2003). They 
constitute a significant portion of the urban built environment and an essential housing resource pool for the for the majority of the urban population operating outside of the formal economy (de Soto, 2000). Huchzermeyer (2011) observes that despite informal settlements being depicted as slums falling beyond set standards, these settlements possess individual settlement traits and the potential for improvement. Huchzermeyer and Karam (2006:3) note that rapid population growth, urbanisation rates and weak official housing delivery regimes, render informal settlement interventions ineffective or inadequate. From a livelihood perspective, Satterthwaite (2011) observes that when presented with an opportunity for better housing, the urban poor are unwilling to relocate to the new housing in peri-urban settlements areas for fear of significantly higher time and commuting cost to job opportunities in the CBD. The UN-Habitat (2003), observes that the urban poor are trapped in the state poverty and by default excluded from the formal society and unable to offer any significant contribution to community building.

A global estimate of 863million urban residents lived in informal settlement conditions by 2012, compared with 760 million in 2000 and 650 million in 1990. At 72\%, sub-Saharan Africa (SSA) has one of the highest proportions of the urban population living in informal settlements (UN-Habitat, 2014). Although the SSA region contains just $13 \%$ of the urban population of the developing world, it hosts $25 \%$ of its informal population. Informal settlements are a global phenomenon and are known by a variety of names like "Barrios" in Colombia, "Kampungs" in Malaysia, "Favela" in Brazil, "Chabolas" in Spain, "Kibera" in Kenya and "Komboni" in Zambia. On a global scale these settlements will provide shelter for half the global urban population over the next 2 decades, yet there is minimal collective impetus to find solutions to integrate them into the formal society (UN-Habitat, 2012).

\subsection{Urban Sustainability}

Sustainable development in the city context relates to development that achieves environmental and developmental objectives (Satterthwaite, 2016). The concept of urban sustainability encompasses the social, economic, ecological, physical and political dimensions of sustainability, where physical sustainability considers the capacity of development interventions to enhance the liveability of urban infrastructure for urban resident without affecting the urban region environment (Allen, 2009). Urban sustainability became the clarion call for New Urban Agenda in the quest for global sustainable urban development and desirable state of urban conditions at all levels (Adinyira, E., Oteng-Seifah, S and Adjei-Kumi, T, 2007). It has been defined as the state of urbanization that complies with the principles of sustainable development and can be evaluated from an economic, social, environmental and social perspective (Shen, Peng, Zhang \& Wu, 2012). It looks at the challenge of resolving urban problems on the understanding that urban centres possess the inherent potential to resolve their own challenges (EU Commission, 1996).

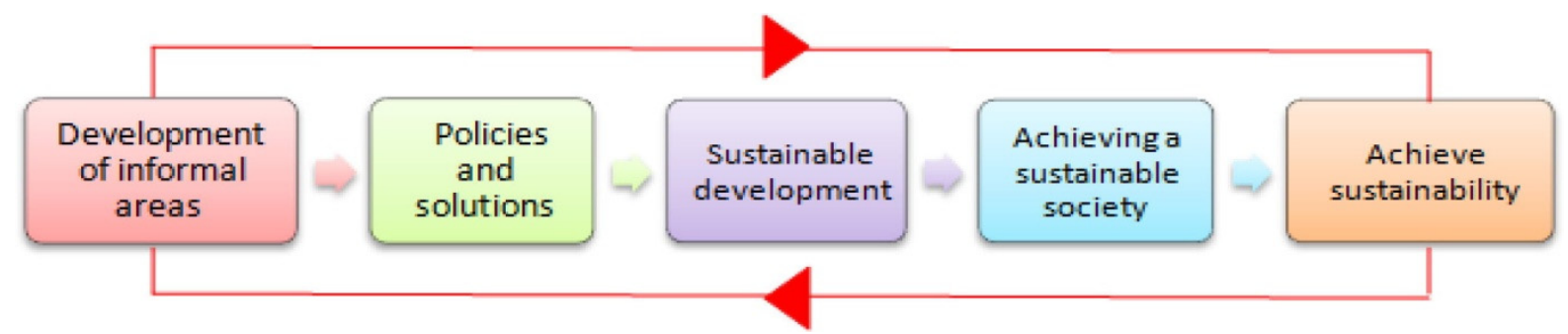

Figure 1. The relationship between informal areas and sustainability

Source: Saad, Fikry \& Hasan, 2019.

\subsection{Informal Urban Settlements of Lusaka}

With an urbanisation rate at $44 \%$, Zambia remains one of the most urbanised nations in sub-Saharan Africa. The majority of this population is found around the urbanised nodes of Lusaka, the Copperbelt and Southern provinces (Hampwaye and Mweemba, 2012). Lusaka City is one of Zambia's the large urban centre with an estimated population of 2.2 million representing $32 \%$ of the country's urban population (UN-Habitat 2012). Lusaka's annual population grew at a rate of $4 \%$ during the period 1990-2000 which was $25 \%$ higher than the national average for this period (UN- Habitat, 2012). According to the Central Statistics Office (CSO, 2011), 72.9\% of the Zambian population lives in poverty. The overall poverty in urban areas stands at $56.3 \%$. Presently only $20 \%$ of the nation's urban population live in planned and serviced areas and the housing deficit of 3 million units is envisaged by 2030 . The proportion of informal settlement dwellers is projected to rise without mitigation (CSO 2011). The majority of people living in poverty reside in informal settlements in urban areas and rural areas. The informal urban settlements are a refuge for the urban poor characterised by poor living conditions and environmental and health 
hazards (UN-Habitat 2012).

Informal urban settlements in Zambia are largely a post-independence phenomenon caused by the unmitigated rural-urban migration of people (UN Habitat, 2007). They are a consequence of decades of poor state urban planning and explicit government policy. They are areas generally occupied without right or legal title under government regulations. The lack of formal recognition of informal settlements excludes them from benefiting from municipal services and public infrastructure. The absence of administrative or governance structures in the settlements has exacerbated the situation. The settlements are generally characterised by inadequate water and sanitation facilities, poor housing structures and overcrowding making residents susceptible to communicable diseases. Most of these settlements are either located near the city centre in the proximity of industrial areas or in the outskirts of the city along the major roads. They are situated on areas meant for agriculture and housing development or flood prone areas which were categorized as unsuitable for human habitation. Informal urban settlement expansion has continued faster than the rest of formal settlements, spurred on by rapid population growth. These settlements were initially treated as a threat by the state but official policy towards them had by 1972, transitioned from championing their demolition to advocating for settlement upgrading (Makasa, 2010).

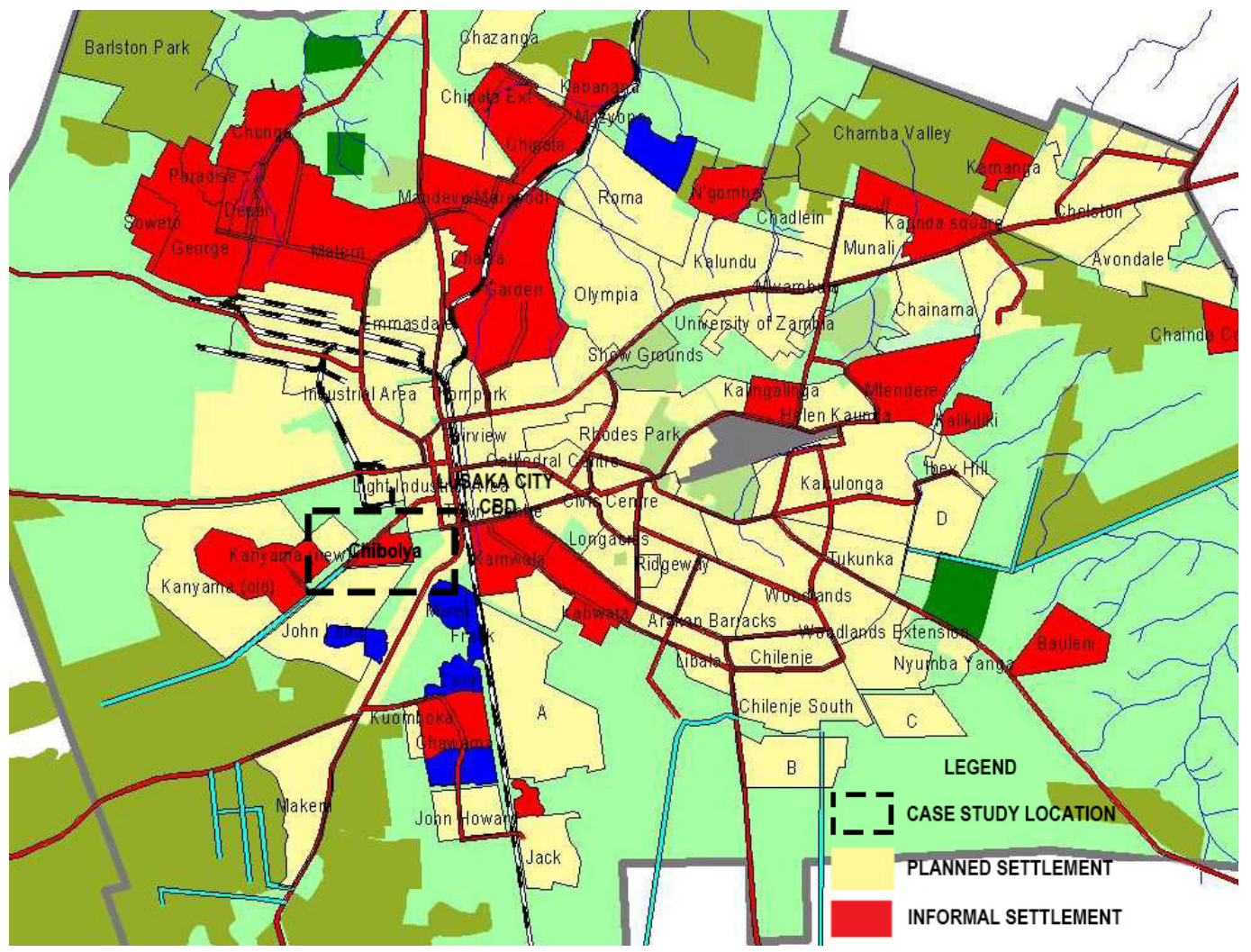

Figure 2. Planned and informal urban settlements of Lusaka

Source: Lusaka City Council, 2012

Zambia is one country that has officially provided a degree of tenure security to informal settlement dwellers. With the help of the World Bank, in 1974, the country undertook some infrastructural upgrading in selected informal communities under the Lusaka Squatter Upgrading Project (LSUP), a pioneering upgrading programme at the time in Africa (Makasa, 2010). Based on the bank's policy on funding urban development in developing countries, the programme involved the provision of basic housing infrastructure, community services, loans for building materials and providing tenure security by facilitating for land regularisation and titling. As support, the Government passed the Housing (Statutory and Improvement Areas) (HSIA) Act of 1974 empowering local councils to give informal settlement residents tenure security and provide basic social facilities. City councils could declare informal settlements as Improvement Areas, representing a major shift in policy from demolition to regularising and servicing them (Matibini, 2003). Tenure in informal urban settlements could now be secured by the issuance of a 30 year occupancy certificate. Lusaka city presently has 37 recognised informal settlements, housing over $70 \%$ of the city's population (UN Habitat, 2007). Chibolya is one such settlement that benefited from 
this exercise. It was declared an improvement area on 16th February 1999 (Yasini, 2007).

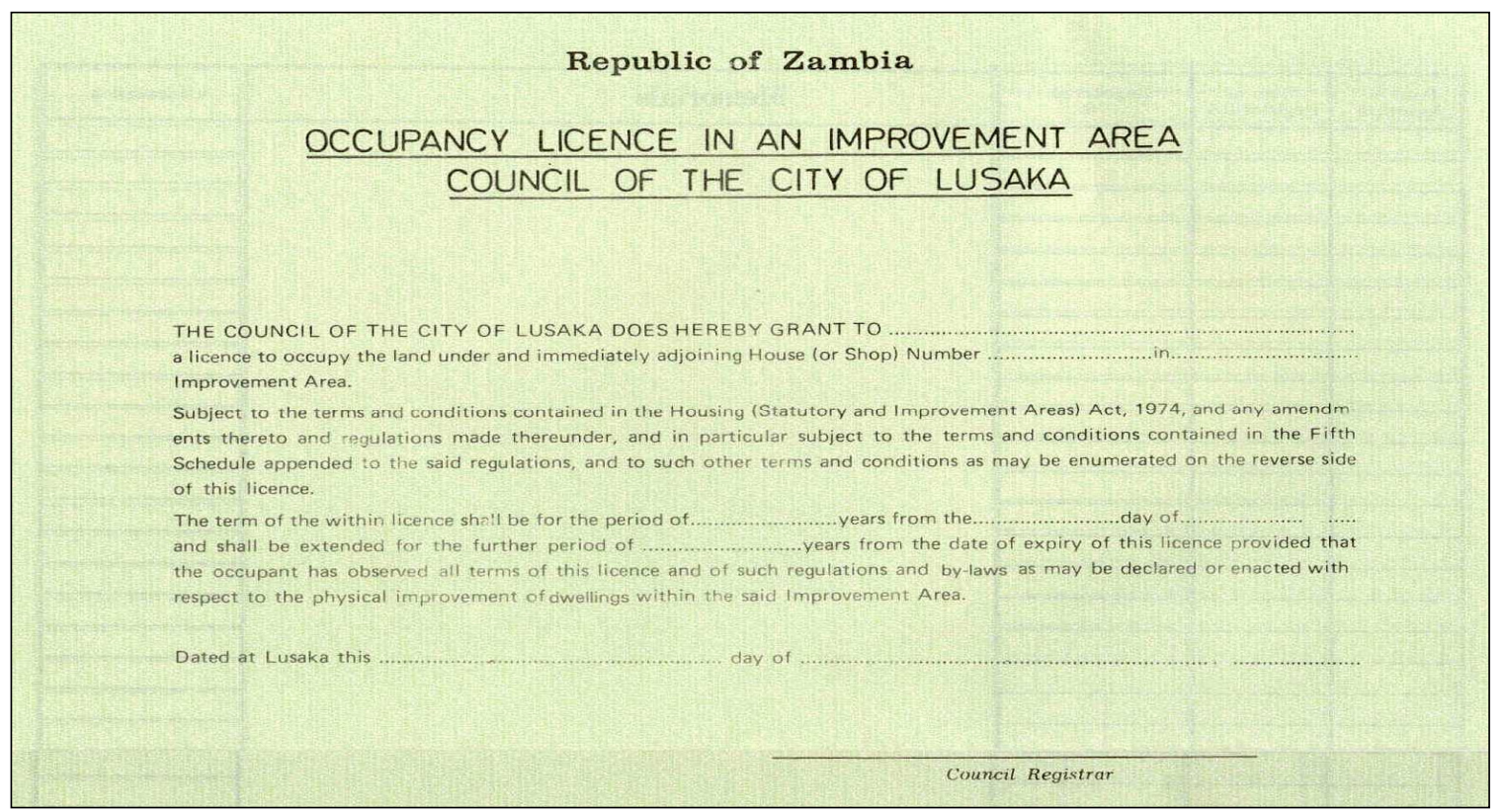

Figure 3. Top half of an occupancy licence

Source: Makasa, 2010

\section{Study Area, Theoretical Framework and Research Methodology}

\subsection{The Study Area: Chibolya}

This study was conducted on Chibolya informal urban settlement located in the centre of Lusaka, the capital city of Zambia. The settlements is an information rich case which represents an inner city type of informal settlement, developed on undesirable land found within the city's CBD. The study area was purposively selected based on the degree of development intervention the settlement has experienced and presents an interesting case from which lessons can be learnt.

Chibolya informal urban settlement began as a compound for council employees in the 1930s. Due to poor sanitation in the original settlement residents were moved to new housing in nearby Kamwala Township. The abandoned compound was later occupied by squatters comprising people employed in the rapidly expanding Lusaka Central business district (CBD). The residents of this area were involved in illicit beer brewing, selling drugs, temporal work and petty trading. The community lived in makeshift shacks made of mud bricks and grass thatched roofs. The settlement had a generally poor physical environment which was compounded by the poor soil drainage in the area. Existing outside the realm of formality and legal structures, the settlement had no social or public infrastructure for a long time which contributed to the high levels of squalor and criminality (Yasini, 2007).

Chibolya is located about a kilometre south of the CBD on the outskirts of the commercial centre. The settlement is bordered by the south-end of Lusaka CBD to the north-eastern boundary and by the informal urban settlements of Kanyama, John Laing and Misisi on the western, southern and south- eastern boundaries respectively. The settlement covers an area of about 473,211 square meters. The land surface is generally flat with noticeable limestone outcrops. The settlement is located in Harry Mwanga Nkumbula local government ward 11. Chibolya has a total population of approximately 25,000 , the number of households is estimated at 4,500 and the average household size is 5.6. The population is growing very fast due to high birth rates (Nkonkomalimba and Mumba, 2014, LCC, 2012). 


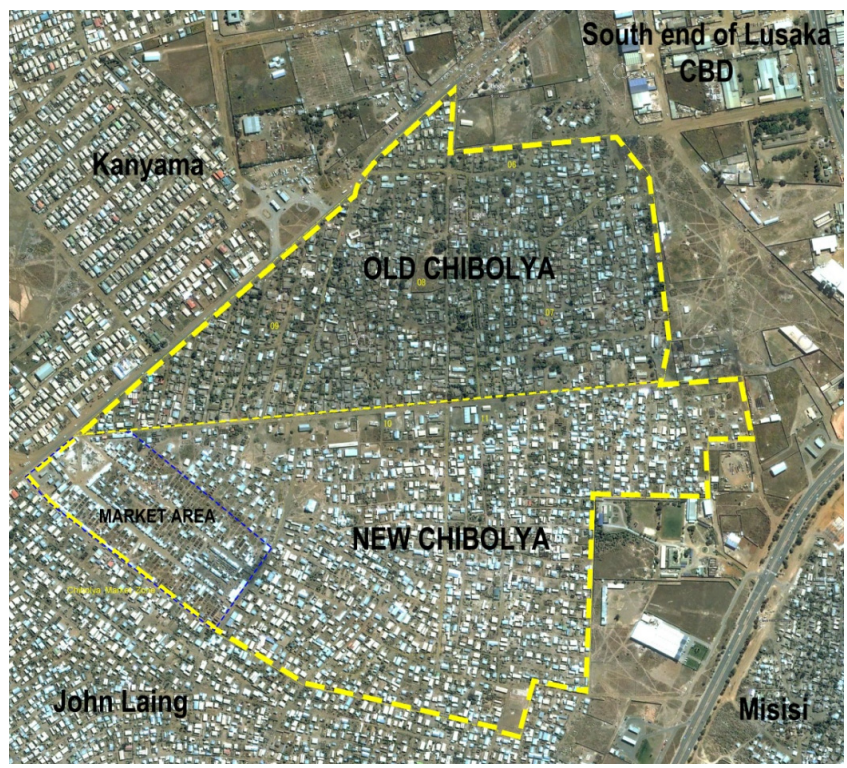

Figure 4. Chibolya settlement and surrounding areas

The settlement has a multi-ethnic character comprising of a mix of people from all tribes of Zambia and some immigrants from neighbouring countries. There is no observed domination by any single ethnic group, with Nyanja and Bemba being the common local languages spoken. A number of Community Based Organisations (CBOs) operate within the settlement. The CBOs are organisations formed by residents to manage a common purpose. They include church organizations, women's clubs/groups, youth clubs/groups and market committees. Without affordable state sponsored low-cost housing options, new migrants to Lusaka continue to seek residence in Settlements like Chibolya. In 2008, LCC embarked on registration of the housing units in Chibolya under the ground rate project. Under this project, houses are allocated numbers and the occupants pay US\$2.4 ground rent and US\$2 for service delivery. Services include provision of roads and street lighting, drainages and garbage collection. Most of the residents have however abandoned the service fees because Lusaka City Council (LCC) has not honoured its obligation (Habasonda, 2012).

\subsection{The Explanatory Theory of Environment-Behaviour Relations.}

Since informal settlement space is built space, it should therefore be evaluated within its circumstances (Low, 1996). Rapoport (2001) proposes the use of the explanatory theory of Environment-Behaviour Relations (EBR) to better understand the production and use of built environment space. EBR involves the structured analysis of the interaction between man and his built environment. The model established by Rapoport, (2001) suggests that the assessment of the built-environment relies on evaluative variables that arise from culture (Figure 4).

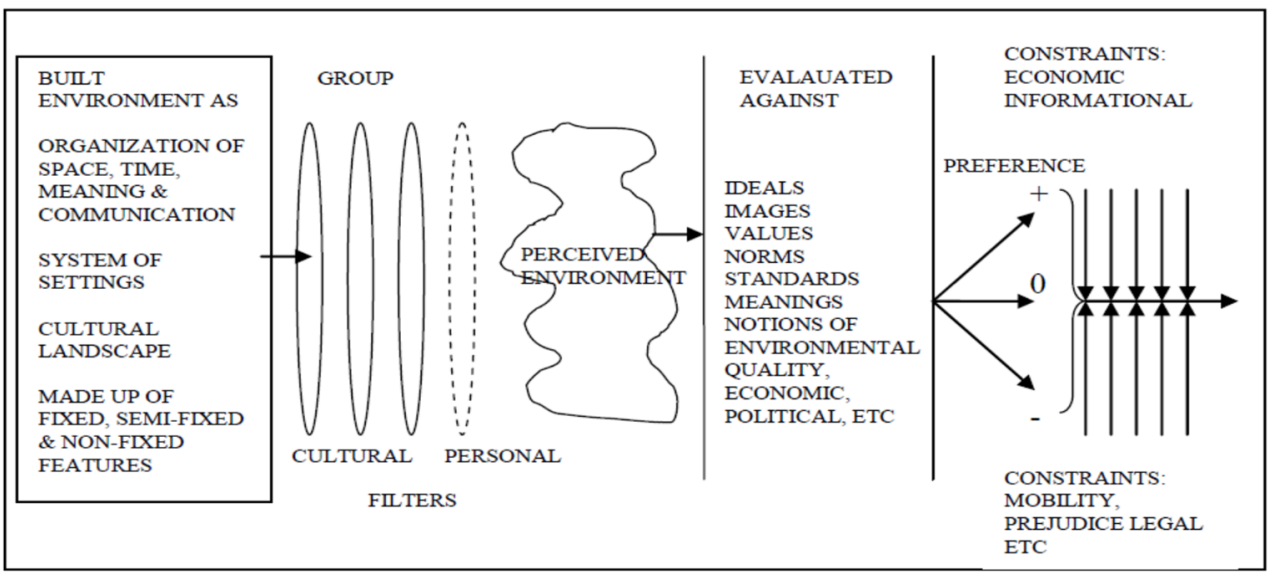

Figure 5. Model of evaluative process of environmental quality based on user's perception

Source: Rapoport, (2001) 
The built environment is a manifestation of local culture. Any built environment is filtered by local cultural factors or a system of settings organized over space, time, meaning \& communication wherein systems of activities occur (Rapoport, 2001). Rapoport accordingly argues that housing choice is a consequence of the user's preferences formed through this evaluation under the imposition of external constraints i.e. economic, political, informational, prejudice, legal, etc. The theory explains and empirically tests the connections and interaction patterns between man and the environment. Rapoport (1980) observes that the main function of design is to improve the environment and improving environmental quality is also a function of informal settlement upgrading which is a form improving the built environment. Several factors guide this function and guide man's desire to create a better environment. According to Moffatt \& Kohler (2008) the built environment as a composition of facilities designed for human needs. These facilities and their relative location create systems which define the composition of built elements, their physical settings and the populations they influence. The approach of defining or 'dismantling' environmental components offers an appropriate conceptual framework for evaluating the informal settlement space and addressing the issues of the impact of improvements on environmental quality including the aspects of compatibility, affordability and lifestyles. Thus a suitable study approach to the informal urban settlement would require an evaluation of forms of shelters, organization of space, system of settings, cultural landscape and other fixed, semi-fixed and non-fixed features, including all the actors within the study context.

\subsection{Research Methods}

Empirical data was collected from households in Chibolya informal settlement of Lusaka. The study employed the case study method with qualitative examination (Creswell \& Clark 2017:4). Chibolya in, Lusaka was used as the study area as it is an information rich setting which has undergone a number of development interventions from both government and cooperating partners with varied outcomes (Neuman, 2011) . Chibolya, located in close proximity to the city CBD but still lacking in the infrastructure and services found in surrounding planned settlements, typifies the informal urban settlement model. The paper relies on both secondary information and field data obtained from field work conducted in Chibolya in February, 2014 and June to September, 2019 to complement the literature survey.

Primary data was collected from respondents using a combination of data collection tools. Participant observation, documentary review, interviews and questionnaire were techniques employed to gain an in-depth appreciation of the study subject. Both structured and unstructured interviews were administered to the sample population. Structured interviews were conducted with household respondents from an interview guide and the unstructured interviews were used to supplement and offer the respondent s unbiased perceptions. Structured questionnaires were conducted with the aim of establishing the resident perception of the quality of their built environment and develop a deeper understanding of the study subject (Yin 2003). The population sample comprised of 5\% of the settlement households. The study clusters were mirrored on the 6 zones of the study settlement. The total population of 220 households interviewed during the household survey offered a manageable sample to carry out a qualitative study within a defined neighbourhood space. This involved the administration of 220 questionnaires to households selected using the purposive random sampling techniques. All participants in the selected households were required to be residents of Chibolya and had to give consent for the purpose of a brief 5-10 minutes interview. 6 data collectors aided in administering the questionnaires by going to the 6 zones of Chibolya settlement and tasked with collecting data from a minimum of 35 households each. To complement the questionnaires in the settlement, 08 open-ended and semi-structured key informant interviews with the Ministry of Local Government and Housing officials, Lusaka council officials and public utility operators involved in service provision were conducted. These stakeholders were met in order to acquire information on facts regarding development policy and development interventions that have occurred in Chibolya or the lack thereof. 
Table 1. Study units of inquiry

\begin{tabular}{lllll}
\hline Ref. & Respondent/Participant & Population & Sample & Response \\
\hline 01 & Households & 4500 & 220 & $220(100 \%)$ \\
\hline 02 & $\begin{array}{l}\text { Community Members, Ward Councilors Representative } \\
\text { Ward Development Committee Officials, Water Trust } \\
\end{array}$ & & 15 & 15 \\
& Officials and CBO Officials & & \\
\hline 03 & $\begin{array}{l}\text { Ministry of Local Government Officers, Lusaka City Council } \\
\text { and District Planning Officers, Lusaka Water and Sanitation } \\
\text { Company Officials. }\end{array}$ & & 08 & 08 \\
& & & \\
\hline
\end{tabular}

Source: Author

Desk review involving reviewing of secondary data was employed for this study. Secondary information included data collected from a variety of sources including international scientific journals, government policy documents, research articles and seminar papers. Key local organisations met included the Ward Development Committee, community based organisations (CBOs) operating in the settlement, Water Trust management and water vendors and the sanitation agencies provided information regarding development interventions conducted in the settlement and the effectiveness of such interventions. General observations were conducted through notes and photographs taken to establish existing built environment conditions. The collected information was presented in tables and graphically for analysis. Data was analysed qualitatively through textual analysis and documentary review. The Statistical Package for the Social Sciences (SPSS) Version 21 was used to analyse the data. Numerical statistics and descriptive analysis was employed to provide clarity on development interventions that have been conducted and their impact on the settlements sustainability.

\section{Result and Findings}

\subsection{General Characteristics of the Sample}

The data analyzed in this section is derived from the survey conducted by the author. Household characteristics considered, include household structures, level of education, duration of stay in the settlement, and the reasons for staying in Chibolya. The sampling frame is fairly balanced in terms of gender although the male respondents slightly edged their female counterparts. Male headed households made up two-thirds of the neighbourhood sample as indicated in Table 2, while 31.6\% of the study population were female headed households comprising mostly of elderly women. A total of 115 males and 105 females, ranging from 18 to 72 years of age participated in the study $(\mathrm{N}=220)$. In total, 81 respondents were under the age of 35 , whilst 139 were 35 years and above. 
Table 2. Socio-economic survey of Chibolya respondents sample demographics $(\mathrm{N}=220)$

\begin{tabular}{|c|c|c|c|}
\hline Variables & Percentage & Variables & Percentage \\
\hline Gender Of Household Head & & Highest Education Attained & \\
\hline Male & 68.4 & No formal education & 16 \\
\hline Female & 31.6 & Primary education & 37 \\
\hline Age & & Secondary education & 30 \\
\hline Under 35 & 36.8 & Vocational education & 11 \\
\hline Above 35 & 63.2 & College & 6 \\
\hline Marital Status & & University & - \\
\hline Unmarried & 47 & Duration of Stay in Chibolya & \\
\hline Married & 53 & Below 4years & 9.6 \\
\hline Position & & $5-9$ years & 36.5 \\
\hline Landlord & 59.4 & $10-15$ years & 32.7 \\
\hline Tenant & 40.6 & Above 15 years & 21.2 \\
\hline Household income & & Reason for Staying in Settlement & \\
\hline 0 to 999 & 20.5 & Affordable Rent & 32.8 \\
\hline 1000 to 3999 & 75.4 & Affordable Rent/Proximity to work & 19.4 \\
\hline \multirow[t]{2}{*}{ Over 4000} & 4.1 & $\begin{array}{l}\text { Proximity to self employment } \\
\text { opportunity }\end{array}$ & 22.0 \\
\hline & & Proximity to self employment & 25.8 \\
\hline
\end{tabular}

\subsubsection{Spatial Needs}

Chibolya residents are generally unsatisfied with their spatial conditions. $83 \%$ of respondents were unsatisfied with the condition of the surrounding environment. Most respondents pointed to the generally poor environmental situation evident in the community. Others indicated the lack of safe public spaces for children and lack of space for activities such as trading, social interaction and crop cultivation as reasons for such responses. Most respondents (71\%) were however, satisfied with their accommodation if the settlement (see table 6). The majority of respondents pointed to the proximity of the settlement to the CBD as the reason why they felt comfortable despite the accommodation being far less that in similar settlements on the city's peripheral areas. The fact that close to $60 \%$ of the household are owner occupied residences also affects perceptions of residential satisfaction.

Table 3. Spatial needs of Chibolya residents

\begin{tabular}{lcrrrr}
\hline & Are Resident's Spatial Needs Met? & Frequency & Percent (\%) & Valid \% & Cumulative \% \\
\hline \multirow{2}{*}{ Valid } & Yes & 37 & 16.8 & 16.8 & 16.8 \\
& No & 183 & 83.2 & 83.2 & 100.0 \\
\hline \multirow{2}{*}{ Total } & & 220 & 100.0 & 100.0 & \\
\hline \multicolumn{2}{c}{ Is the Accommodation Satisfactory? } & & & & \\
\hline \multirow{2}{*}{ Valid } & Yes & 156 & 70.9 & 70.9 & 70.9 \\
& No & 64 & 20.1 & 20.1 & 100.0 \\
\hline Total & & 220 & 100.0 & 100.0 & \\
\hline
\end{tabular}

\subsection{Chibolya's Sustainability Challenge}

\subsubsection{Tenure Security}

Chibolya presently is recognised as an improvement area. The recognition comes with the offer of a degree of 
tenure for landlords. According to the settlement analysis in figure 6, only 15 properties in the whole settlement had secured occupancy licences at the time of this study. Most household in the older part of the settlement (Zones $6,7,8 \& 9$ on figure 6 ) had land records registered with the council while $30 \%$ of all households in the settlement lack any form of ownership documents. The landholders attributed their reluctance to formalise their ownership in part due to the fear of anticipated rates and charges and partly due to the demise of original owners of the properties.

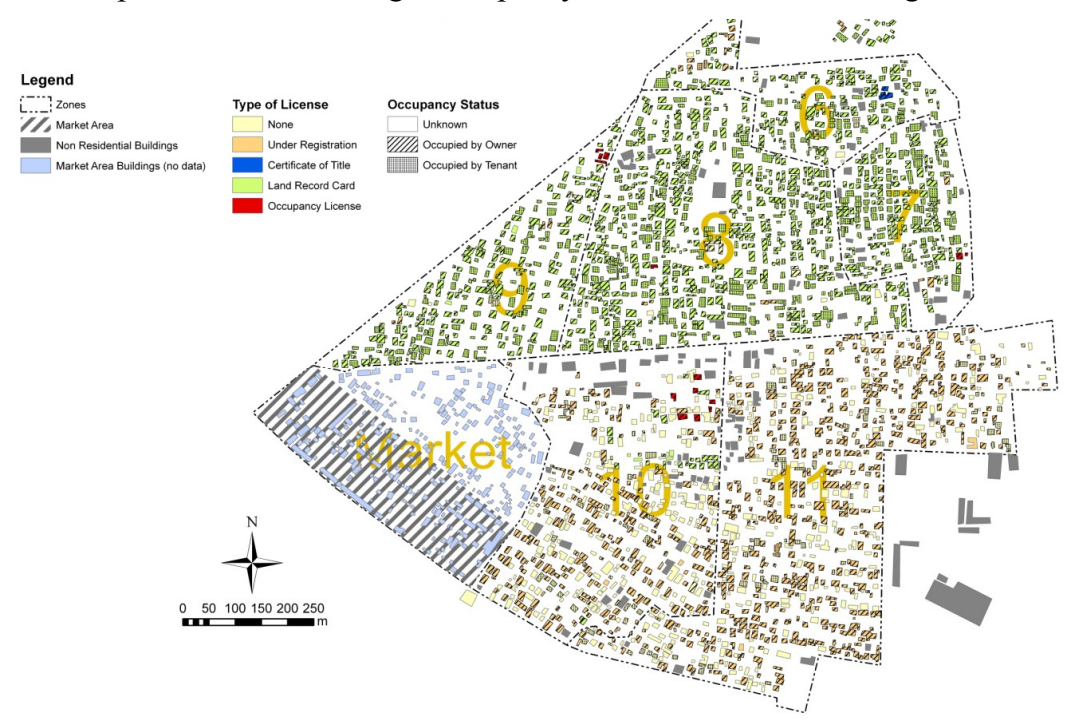

Figure 6. Legal status of properties in Chibolya settlement

\subsubsection{Infrastructure}

Key informant interviews with state actors established that the local is not presently mandated to provide any public facilities or services to informal settlements. However since the area was declared an improvement area, the council has embarked on offering a limited level of development control, mostly focussed on developments along the main roads into the settlement. Chibolya settlement has one main tarred road which acts as the main artery into the settlement. Other roads and lanes in the settlement are un-serviced dirt roads which receive little maintenance from the community or local authority. The settlement has one government school, which lacks the size and capacity of the needs of the settlement. Some school going children have to walk long distances to schools in other settlements or attend fee paying community schools like Zambia Open Community School, Wisdom Apostolic Faith, and Freedom Literacy Club (JICA, 2001: 2). Focus group discussions noted that community schools have no capacity to accommodate those who cannot find places in the government school. This has led to high dropout and illiteracy rates among school-aged children and youths in the settlement. City and government officials interviewed bemoaned the lack of land to construct social amenities in Chibolya.

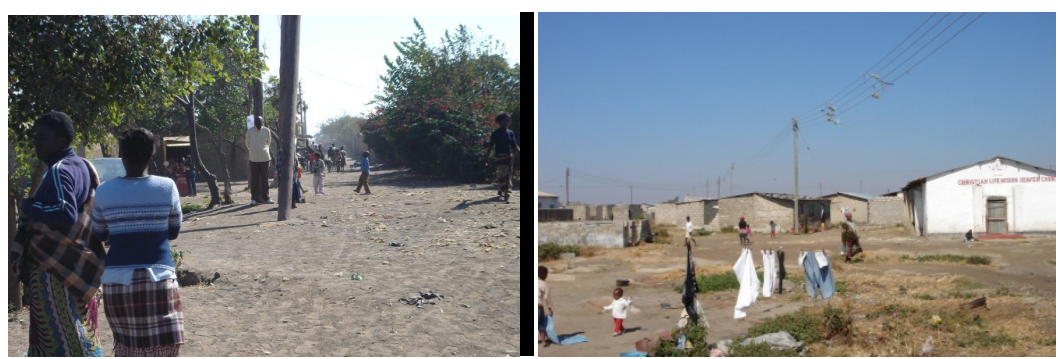

Figure 7. Typical condition of roads in Chibolya

The settlement survey showed that Chibolya has a single police post and a neighbourhood watch group called the Chibolya Crime Prevention and Control Association. Community leaders noted that crime levels in the settlement remains high though no actual statistics for crime prevalence could be found. This is attributed to lack of effective policing, drug abuse, unemployment and a general breakdown in law and order. It was also noted that the settlement lacks adequate health facilities. Most patients and expectant mothers opt to walk long distances to facilities in neighbouring settlements. The focus group blamed the lack of public parks and recreation facilities to keep the 
youth occupied, for the escalating teenage pregnancies and alcohol and drug abuse in the community.

\subsubsection{Water Supply}

Since Chibolya exists in a state of informality, public services are generally not available. Respondents recognise the availability, accessibility, cost and quality of water as major concerns facing Chibolya. Respondents noted a general shortage of sources of clean drinking water in Chibolya, with the whole settlement having only 19 communal water points (see figure 9) leading to most residents being located far from the water points. In instances where such points are available, the ability of residents to access the service is low because of the fees charged to draw water. This has led to some residents digging shallow wells, from which they draw untreated water for their daily use. The focus group revealed that for a long time, Chibolya did not have safe and clean water sources, until the Lusaka water and sewerage company (LWSC), facilitated provision of clean water. LWSC is the licensed service provider in the area through a Water Trust. The Chibolya Water Trust (WT) a CBO operating in the community explained that it supplies clean water to the community through public tap stands and individual connections. The successful establishment of the WT created interest among donors and other NGOs involved in promoting the provision of water and sanitation in informal settlements.

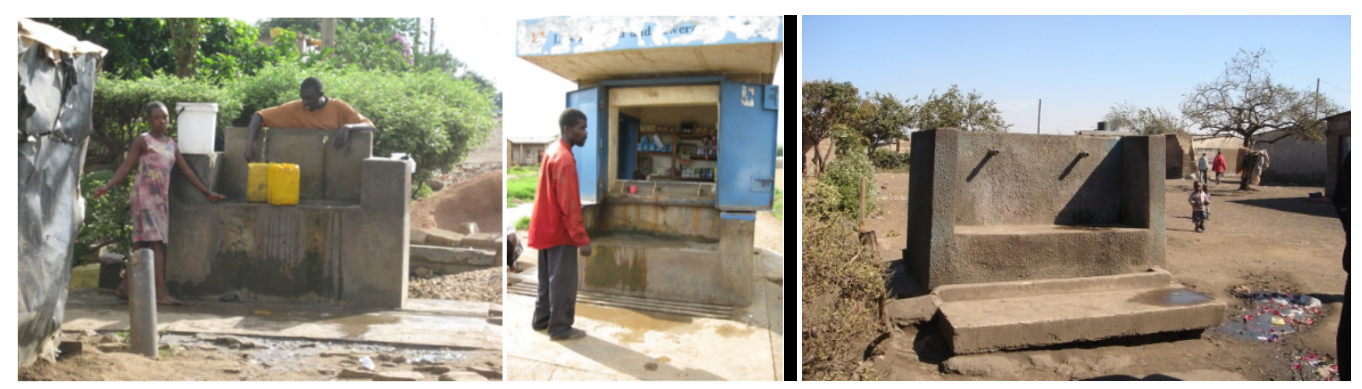

Figure 8. Chibolya residents drawing water at a community stand pipe, WT kiosk and a disused LWSC commercial water stand

Source: Patole M., 2010, Author.

The WT was introduced by Care International with support funding from the British government's Department for International Development (DFID). The WT is a community-based scheme which is more advanced than the traditional community water vendors. WTs abstract underground water, which they treat and distribute within the community. With an established formal infrastructure, an administrative structure and operating under a cost recovery principle, their operations are more akin to a mini-utility than a vendor, (Nkonkomalimba and Mumba, 2014). The Chibolya WT targeted providing at least 20 litres per capita per day to $60 \%$ of the settlement population. The WT are not regulated with respect to tariffs, like other vendors and charge about five times more per litre than the Commercial Utility. They are however, regulated with respect to minimum hours of service, water quality and reporting (Patole, 2010). Local authority officials acknowledged the WT's contribution in actualising the right to safe drinking water and sanitation. WTs have contributed to improved availability of quality water to the community. The sanitation improvement efforts have been supplemented by other NGOs and CBOs including Children international, Human Settlements Zambia (HUZA) and Zambia Open Community Schools (ZOCS), Water and Sanitation for the Urban Poor (WSUP). The Children International financed the establishment of 5 water kiosks between 2010 and 2013, with WSUP leading interventions in the water and sanitation sector. However the security situation in Chibolya remains volatile thus discouraging interested agencies in expanding their interventions.

\subsubsection{Sanitation}

Sanitation refers to the provision of facilities and services for the safe disposal of human waste. Sanitation is a major challenge in Chibolya, which lacks improved sanitation infrastructure for waste disposal and sewerage. 25\% of the residents do not have sanitation facilities (NWASCO \& DTF, 2005). Most landlords interviewed admitted to not providing toilets for their tenants. It was observed that the common sanitary facilities found in the settlement include ordinary and VIP pit latrines, open defecation and 'flying toilets'. Flying toilets refers to the practice of defecating in a plastic bag for disposal in the open spaces at night. The phenomenon of flying toilets is increasing as some residents cannot afford the user fees charged by public facilities and these facilities are inaccessible at night due in part to security concerns. The majority of Chibolya residents (92.7\%) use pit latrines with only $7.3 \%$ using flushing toilets (JICA, 2009). 


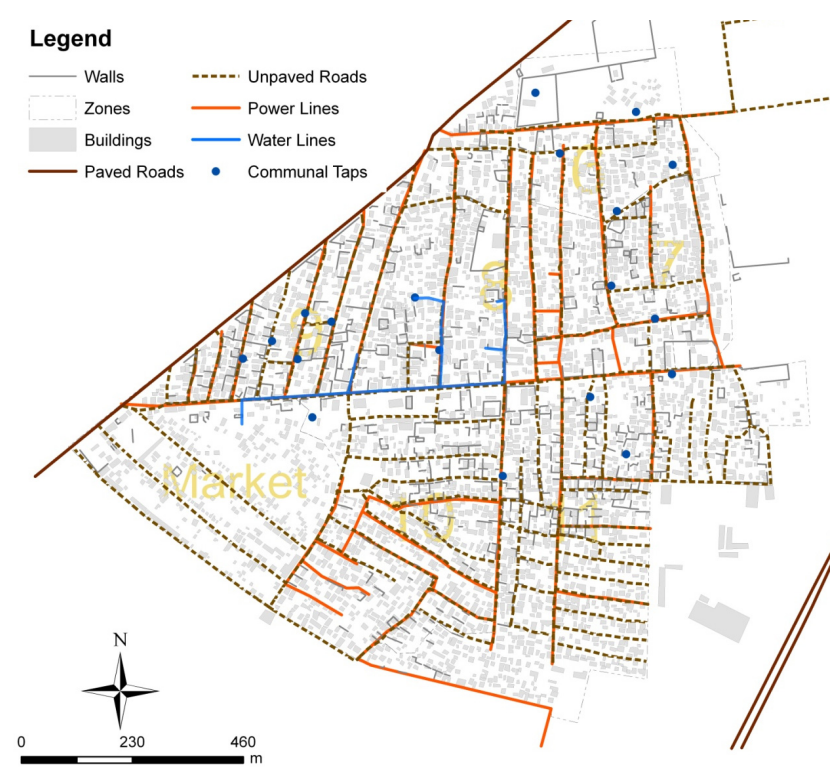

Figure 9. Existing utilities in Chibolya

It was noted that the existing latrines were inconveniently located free-standing units which were in most cases filthy, prone to collapse, and poorly built of either mud bricks or corrugated iron sheets or plastics and cardboard. They are built very close to houses, with more than one household sharing a single facility. The lack of room for building new toilets has led some residents to empty their latrines manually and bury the sludge on their residential plots. The existing toilet facilities produce a very bad odour especially during the hot season. During the rainy season, when the area gets flooded with rainy water, the waste from the toilets overflows onto the soil and into shallow water wells, leading to serious water contamination.

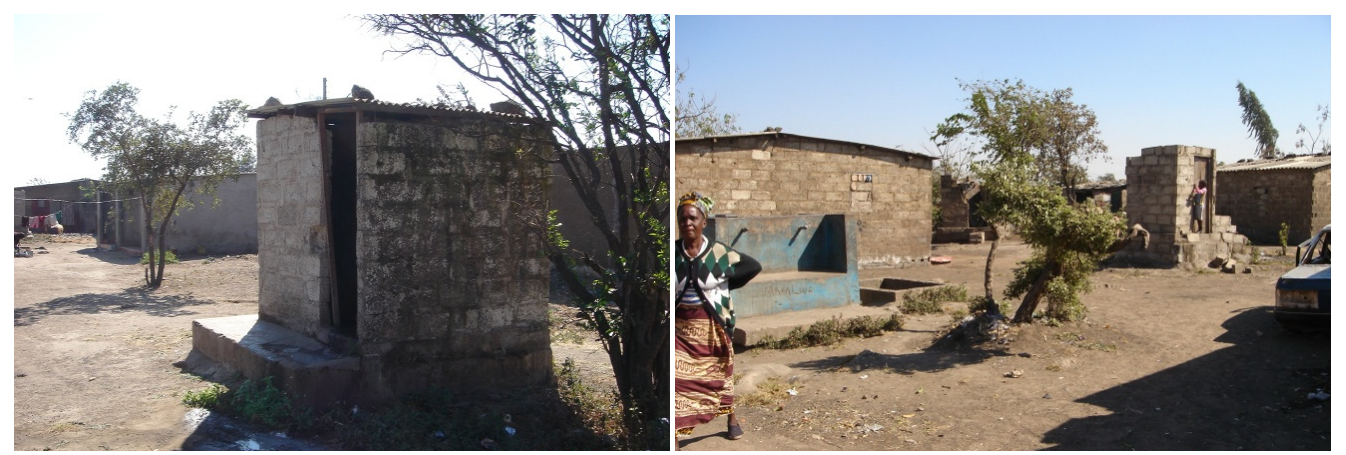

Figure 10. Typical communal pit latrines in the settlement

International Non-Governmental organisations (NGO) and local stakeholders are investing in improved sanitation in Chibolya. Apart from the water infrastructure, CARE International has supported the provision of residential toilets and public sanitation facilities. The Water Trust (WT) also works to improve sanitation by managing fee paying waterborne toilets. The WT has the potential to take on further sanitation and solid waste management responsibility in Chibolya. The WT public toilets are relatively cheaper per visit compared to privately owned toilets. Public toilets provide an avenue for proper disposal of human waste and reduce pollution and environmental degradation in the community. Improving the dire sanitation situation in the settlement is essential in order to actualise the right to life and human dignity.

\subsubsection{Energy Availability}

Chibolya resident acknowledged using charcoal for their fuel needs. The charcoal is supplied from outside Lusaka and is commercially sold on the southern periphery (market area) of the settlement. The government official interviewed acknowledged that the supply of cheap charcoal fuel for the urban poor is leading to massive deforestation and land degradation at the points of wood extraction and production. The electrification of 
households in Chibolya, which involves connection to the major grid system, is extremely limited. Chibolya however has been more fortunate, due in part to its proximity to the City's CBD. Power transmission lines and electricity has been supplied to the community by the national utility. However the majority of the respondents (65\%) lack access to the commodity because of exorbitant charges for connection and use on the utility company's pre-paid metering system (see figure 9). In some instances, Chibolya residents have illegally created unsafe connections to siphon electricity from legally connected neighbouring buildings, often resulting in electrocution deaths and fires. The availability of affordable energy is essential to foster economic development and is necessary to aid resident's attempts to graduate from a subsistence economy.

\subsubsection{Solid Waste Management}

The management of solid waste in Zambia is generally problematic and a critical problem in Chibolya in particular. The strategic location of Chibolya between other informal settlements to the west and commercial and industrial activities to the north-east presents a peculiar situation in which the settlement is exposed to a wide range of domestic and industrial waste. The common forms of solid waste observed during the settlement survey include chemicals, plastic, metals, wood, paper, textile and transportation industry waste.

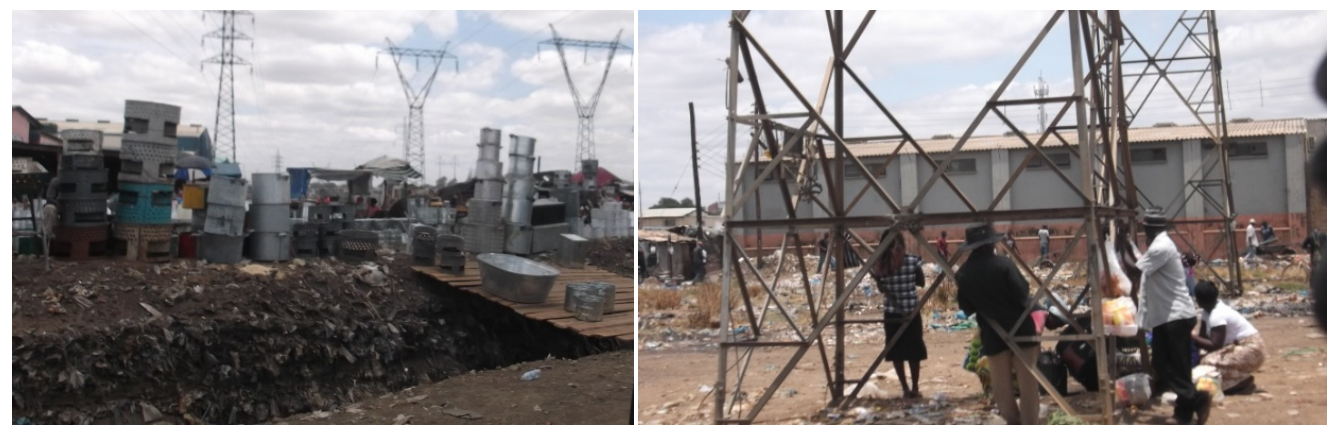

Figure 11. Typical neighbourhood scenes of uncollected garbage with unconcerned residents going about their business

One of the visible environmental concerns is the heaps of uncollected waste, which is common along the roads and in the few public spaces. Indiscriminate littering was observed around the settlement with years of uncollected garbage lining street sides, due in part to the absence of garbage collection services. The local authority acknowledged that the garbage is a source of diseases transmitted by rodents and flies. The settlement is filled with a stench of smells from a nearby abattoir and smoky from illicit spirit 'kachasu' brewing which is rampant in the area. The settlement has no drainage system, which poses a serious health and environmental hazard. At a national level, National Water Supply and Sanitation Council (NWASCO) noted that the investment in the Water Supply and Sanitation (WSS) sector mainly focused on improving and increasing access to water as opposed to sanitation leading to a poor sanitation coverage of $57 \%$ for urban and $43 \%$ for rural areas respectively (Nkonkomalimba \& Mumba, 2014).

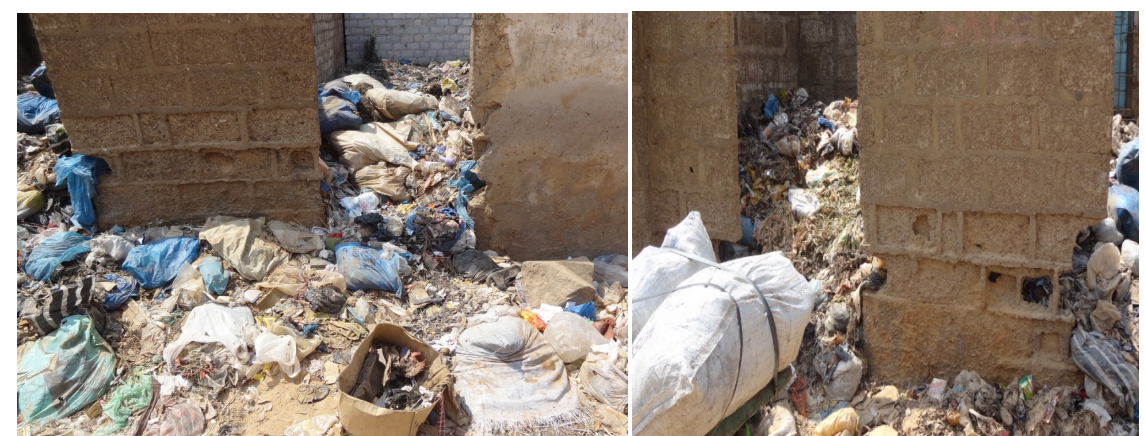

Figure 12. Waste dumped in a disused building

Source: Habasonda, 2012

The focus group acknowledged that Community Based Enterprises (CBEs) involved in waste management were established in Chibolya. The CBEs are engaged in the primary collection of garbage from the households to the 
main skip bins, while the Lusaka city council are tasked with waste disposal from the skip bins to the Main City dump site. The Chibolya CBEs have not been operational due to the lack of skip bins used for the collection of waste and the non-payment of garbage collection service charges by residents. This has resulted in increased illegal dumping of garbage on open space abandoned buildings and into the stream that border the northern and eastern edges of the settlement.

\subsubsection{Provision of Housing}

The materials used to build houses are indicative of the permanence of slum housing. The UNCHS (1997) defines housing permanence as the percentage of dwelling units which are likely to last twenty or more years given normal maintenance and repair, with due regard for locational and environmental hazards.

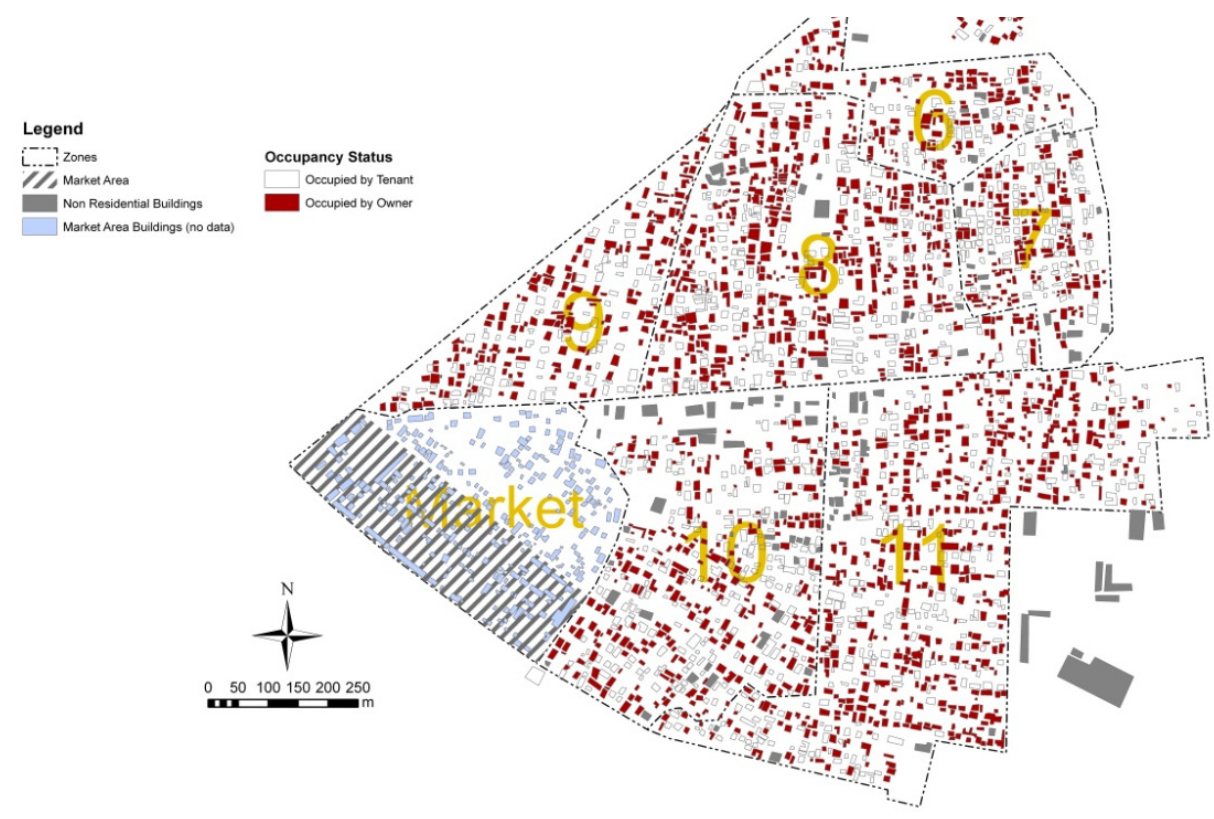

Figure 13. Chibolya household occupancy status

Housing in Chibolya was observed to be in various stages of permanence. Most houses in Chibolya were built without layout plans from the council. The housing in Chibolya is dilapidated (see figure 14) and presents a danger to health because of the inherent overcrowding coupled with poor ventilation which exposes residents to many respiratory diseases. The quality of the houses in new Chibolya differs between the old settlements and the new settlement. The southern part (zones 10 and 11) has for the most part, brick and mortar houses which are well spaced. The northern part (zones 6, 7, 8 and 9) has houses built very close to each other mostly built of mud bricks, cast off metal roofing sheets and other inferior building materials. A random house assessment during the study noted the poor quality of materials susceptible to collapse during heavy rains. The bulk of the housing stock in Chibolya is made up of single and double roomed row housing units locally called 'Mudadada', which are owned and managed by private landlords. This appears to be the most effective form housing as respondents acknowledged the low cost considerations when renting in these settlements.
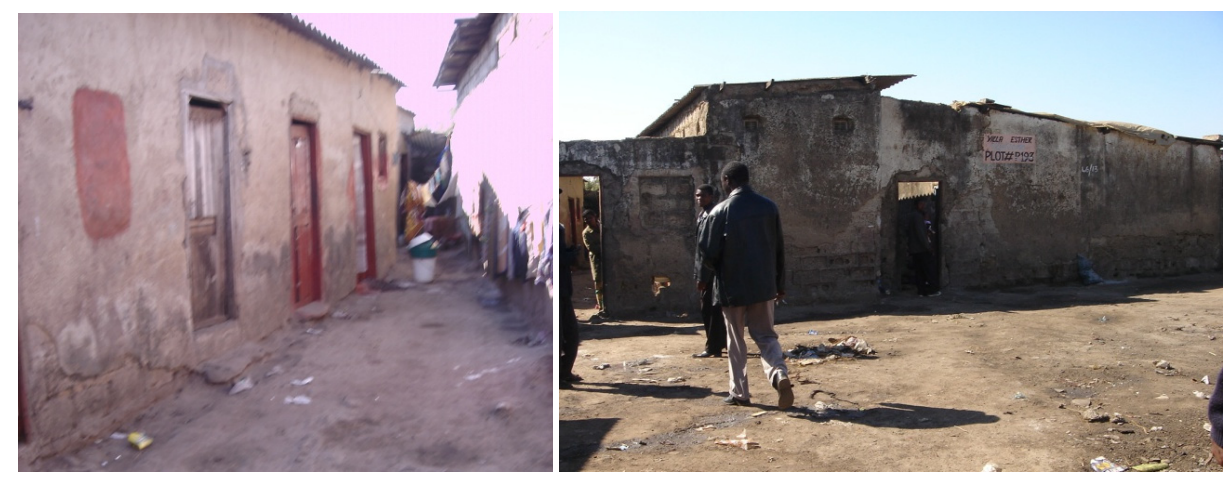

Figure 14. Typical dilapidated row housing in Chibolya 
The structures in the settlement are owned by landlords who in most cases live in part of the structures with their tenants. The tenants rent single or double roomed units called ' $b o b a$ ', for which they pay a monthly rental to the landlord. The landlords intimated that occupancy turnover is high as residents are constantly changing residence due to evictions, changing rental fees or changing family dynamics. The common family unit in Chibolya is mostly made up of nuclear family unit. The common reasons respondents gave for living in informal settlements include the affordable rentals charged and the proximity to self employment opportunities (see figure 6 and Figure 15). With the settlement being an Improvement Area most property owners have applied for an occupation license but have not yet issued with one by the City council as indicated in figure 6 .

\subsubsection{Settlement Livelihoods}

As Satterthwaite (2011) notes that centrally located high-density informal settlement dwellers value their proximity to income-earning opportunities. The lower a person's income, the more premium they put on residing close to income-earning opportunities. The majority of Chibolya residents earn their livelihoods through employment opportunities which are in close proximity to their neighbourhood. The main source of income for most of the settlement population is through employment in the neighbouring CBD area.

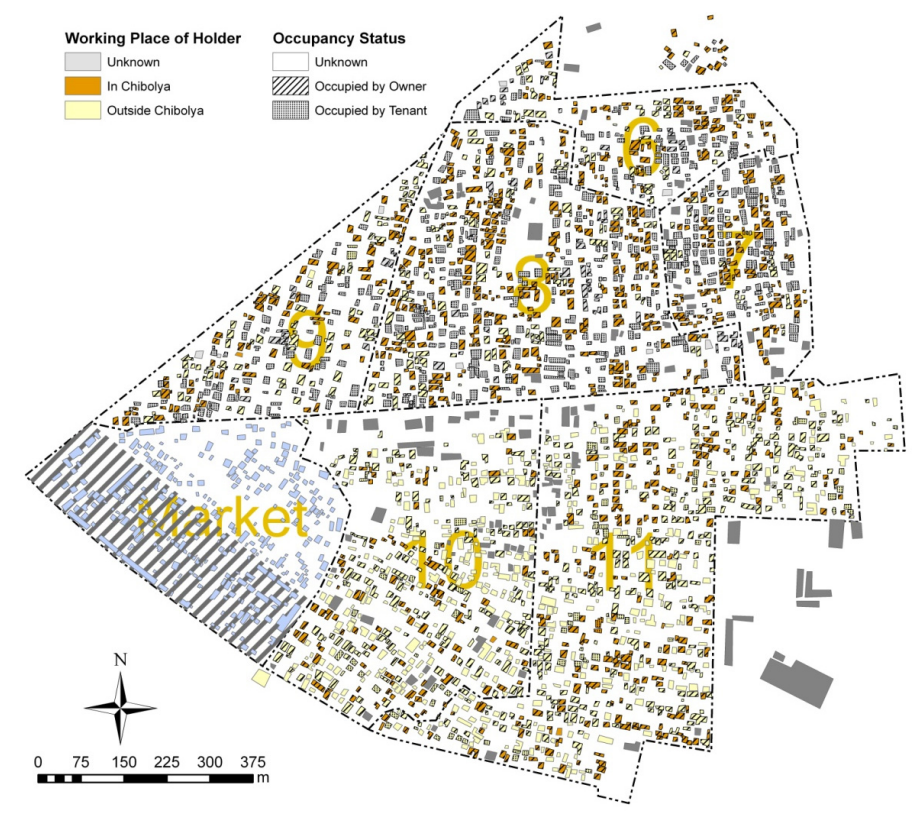

Figure 15. Employment locations for Chibolya residents

Most residents are involved in the service and security industry either as shop attendants, waiters, minibus taxi drivers, fuel attendants, office orderlies or security guards. The other main form of employment demographic in the settlement are the people engaged in the construction sector who find ready sources of employment in the ongoing construction sites in the city and nearby townships. Like most informal settlements, another major economic activity involves the provision of rental housing in the settlement by landlords. Rental housing makes up the majority of housing stock in the settlement. There are various commercial activities taking place around settlement. With concentrated commercial activities at designated market in the settlement and along the main arterial roads that runs through Chibolya. These activities include numerous small shops, food kiosks and makeshift second hand clothes shops. Commercial activities of a recreational nature are also common and include bars and illicit beer taverns which are located all around the settlement.

\section{Conclusion}

Chibolya residents face a multitude of socio-cultural, economic and environmental challenges. This is despite the settlement being their only axis to livelihood opportunities in the formal City. There is a shortage of public services and social amenities in Chibolya. It has been established that the settlement is afflicted by lack of adequate housing, adequate water and sanitation and solid waste services. The contributions of NGOs such as Care International engaged in the provision of social services in informal settlements in Zambia, have significantly contributed to the alleviation of the challenges they face. A Case in point is the Water Trust, which has continued to serve the community. The WTs serve as an alternative to municipal service providers of water and sanitation services in 
Chibolya. It is however unfortunate to note that residents, actually pay more for water services than residents of planned settlements of the city receiving commercial utility services. The shortage of improved sanitation perpetuates the environmental and health risks in the community. In addition, the absence of garbage collection services have led to indiscriminate dumping around the community with garbage remaining uncollected and posing a hazard to both the residents and the environment. The absence of public services poses a major challenge to health, social and environmental quality.

The study shows the informal urban settlement challenge in Lusaka is much more of a poverty of ideas. The government's inability to provide basic infrastructure and services has led to unhealthy living condition. Cooperating partners have made concerted efforts to alleviate the slum challenge but new and more innovative approaches are needed going forward. The government has over the years made several pronouncements on plans for upgrading Chibolya. The state's efforts have however been mere rhetoric and have in no way improved the resident's current housing challenges. Chibolya has undergone transformation over time. It is important to understand the historical perspectives that define its present physical and social realities. The government and supporting agencies have previously provided development interventions to improve living conditions of Chibolya residents but the situation still remains uncertain. The article however also shows that given enabling opportunities as in the case of WTs, NGOs together with the local communities can create development strategies that adequately complement state efforts to improve the social conditions and service provision in informal settlements.

The study proposes that the state and cooperating partners should ensure that tenure provision is extended to all informal settlement residents, so as to encourage investment in housing by landlords and landowners. There is also need to ensure the state and its agencies collaborate with informal settlement residents and cooperating NGOs in collaborative and participatory development interventions in order to achieve affordable and sustainable service provision to the informal settlement as part of their medium to long term goals.

The study was limited by the inability to access limited sections of the settlement where my settlement contacts could not guarantee my safety. Future lines of study can look at the dynamics at play in successful projects such as the WT initiatives in water and sanitation provision in Chibolya and see how successes scored in such initiatives can be replicated in other similar settings.

\section{References}

Adinyira, E., Oteng-Seifah, S., \& Adjei-Kumi, T. (2007). A Review of Urban Sustainability Assessment Methodologies. International Conference on Whole Life Urban Sustainability and ITs Assessment. Glasgow.

Allen, A. (2009). Sustainable Cities or Sustainable Urbanization? Palette Journal of Sustainable Cities, University College London. Retrieved from www.ucl.ac.uk/sustainable-cities

Bernhardt, A., Boushey, H., Dresser, L., \& Tilly, C. (2008). The Gloves-Off Economy: Workplace Standards at the Bottom of America's Labor Market. Champaign, IL: Labor and Employment Relations Association.

Central Statistical Office (CSO). (2011). Zambia 2010 Census of Population and Housing Preliminary Report. Lusaka: Government Printers.

Creswell, J. W., \& Clark, V. L. P. (2017). Designing and Conducting Mixed Methods Research. Thousand Oaks, CA: Sage Publications.

Cronin, V. (2012). Slum Upgrading in India and Kenya: Investigating the Sustainability. University of Cambridge. Retrieved from http://ethos.bl.uk/OrderDetails.do?uin=uk.bl.ethos.550171

de Soto, H. (1989). The Other Path: The Invisible Revolution in the Third World. New York: Harper \& Row.

de Soto, H. (2000). The Mystery of Capital: Why Capitalism Triumphs in the West and Fails Everywhere Else. London: Bantam Press.

Dovey, K. (2013). Informalising Architecture: The Challenge of Informal Settlements. Architectural Design, 83(6), 82-89. https://doi.org/10.1002/ad.1679

Dovey, K., \& Kamalipour, H. (2018). Informal/Formal Morphologies. In Dovey, K., Pafka, E., \& Ristic, M. (Eds.), Mapping Urbanities: Morphologies, Flows, Possibilities (pp. 223-248). New York, NY, USA: Routledge. https://doi.org/10.4324/9781315309163-13

Dovey, K., \& King, R. (2011). Forms of Informality: Morphology and Visibility of Informal Settlements. Built Environment, 37(1), 11-29. https://doi.org/10.2148/benv.37.1.11

Dovey, K., \& King, R. (2012). Informal Urbanism and the Taste for Slums. Tourism Geographies, 14(2), 275-293. https://doi.org/10.1080/14616688.2011.613944 
EU Commission. (1996). Targeted Summary of the European Sustainable Cities Report for Local Authorities. Prepared by the Expert Group on the Urban Environment. XI/519/96. [EU Commission - Working Document].

Fox, S. (2014). The Political Economy of Slums: Theory and Evidence from Sub-Saharan Africa. World Development, 54, 191-203. https://doi.org/10.1016/j.worlddev.2013.08.005

Habasonda, B. G. (2012). Political Ecology of Slum Development: The Case of Kanyama: Zambia. Research Paper. International Institute of Social Studies. The Hague, Netherlands.

Hampwaye, G., \& Mweemba, L. (2012). Chapter 15: Zambia Country Profile. Southern African Regional Universities Association: SARUA Publication.

Huchzermeyer, M. (2011). Cities with 'Slums': From Informal Settlements Eradication to a Right to the City in Africa. Claremont, South Africa: UCT Press.

Huchzermeyer, M., \& Karam, A. (2006). Informal Settlements: A Perpetual Challenge? Cape Town: UCT Press.

Iskander, N., \& Lowe, N. (2010). Hidden talent: Tacit Skill Formation and Labor Market Incorporation of Latino Immigrants in the United States. Journal of Planning Education and Research, 30(1), 132-46. https://doi.org/10.1177/0739456X10380922

Japan International Cooperation Agency (JICA). (2001). The Study on Environmental Improvement of Unplanned Urban Settlements in Lusaka: Final Report Volume 1 (Summary). Nippon Koei Co., Ltd. Global Link Management, Inc. Produced for: Ministry of Local Government and Housing, Republic of Zambia. Retrieved from https://openjicareport.jica.go.jp/pdf/11652658_01.PDF

Japan International Cooperation Agency (JICA). (2009). The Study on Comprehensive Urban Development Plan for the City of Lusaka in the Republic of Zambia: Final Report Volume III (Pre-feasibility Study of Priority Project). KRI International Corp., Nippon Koei Co., Ltd., Japan Engineering Consultants Co., Ltd. Produced for: Ministry of Local Government and Housing, Republic of Zambia.

Kamalipour, H., \& Dovey, K. (2019). Mapping the Visibility of Informal Settlements. Habitat International, 85, 63-75. https://doi.org/10.1016/j.habitatint.2019.01.002

Low, M. S. (1996). Spatializing Culture: The Social Production and Social Construction of Public Space in Costa Rica. American Ethnologist, 23(4), 861 - 879. https://doi.org/10.1525/ae.1996.23.4.02a00100

Lusaka City Council. (2012). Land Information Management for Chaisa: Chaisa Pilot Initiative. Lusaka City Council, Lusaka.

Makasa, P. (2010). The 1996 Zambia National Housing Policy. Ph.D. thesis. Delft Centre for Sustainable Urban Areas, Delft University of Technology, Delft.

Matibini, P. (2003). Land Tenure Initiative - A Legal Assessment. Lusaka City Council, Lusaka.

McFarlane, C. (2012). Rethinking Informality: Politics, Crisis, and the City. Planning Theory \& Practice, 13(1), 89-108. https://doi.org/10.1080/14649357.2012.649951

McFarlane, C., \& Waibel, M. (2012). Urban Informalities: Reflections on the Formal and Informal. Farnham: Ashgate Publishing.

Moffatt, S., \& Kohler, N. (2008). Conceptualizing the Built Environment as a Social-Ecological System. Building Research \& Information, 36(3), 248-268. https://doi.org/10.1080/09613210801928131

Mukhija, A., \& Loukaitou-Sideris, A. (2015). Reading the Informal City: Why and How to Deepen Planners' Understanding of Informality. Journal of Planning Education and Research, 1-11, 35, 444-454. https://doi.org/10.1177/0739456X15591586

Neuman, W. L. (2011). Social Research Methods: Qualitative and Quantitative Approaches (7th Ed.). Boston, Massachusetts: Pearson.

Neuwirth, R. (2012). Stealth of Nations: The Global Rise of the Informal Economy. New York, NY, USA: Anchor Books.

Nkonkomalimba, M., \& Mumba, M. (2014). Sustainability and Equity Review of CARE Zambia's Peri-Urban Water \& Sanitation Model. CARE International. Zambia.

NWASCO \& DTF. (2005). Reaching the Millennium Development Goals for Water Supply and Sanitation in Zambia: The Urban Perspective. Lusaka, Zambia.

Patole, M. (2010). The Effect of Water Services Reforms on Peri-Urban Water Supply in Developing Countries: A 
Case Study of Zambia. Masters Thesis, University of Dundee.

Payne, G. (2001). Lowering the Ladder: Regulatory Frameworks for Sustainable Development. Development in Practice, 11(2-3), 308-18. https://doi.org/10.1080/09614520120056405

Portes, A., Castells, M., \& Benton, L. (Eds.). (1989). The Informal Economy: Studies in Advanced and Less Developed Countries. Baltimore: Johns Hopkins University Press.

Rapoport, A. (1980). Towards a Cross-Culturally Valid Definition of Housing. In Stough R. R., \& Wandersman A. (Eds.), Optimizing Environments: Research, Practice and Theory (pp. 310-316). Washington D.C: EDRA.

Rapoport, A. (2001). Theory, Culture and Housing. Housing, Theory and Society, 17, 145-165. https://doi.org/10.1080/140360900300108573

Richmond, A., Myers, I., \& Namuli, H. (2018). Urban Informality and Vulnerability: A Case Study in Kampala, Uganda. Urban Science, 2, 22. https://doi.org/10.3390/urbansci2010022

Roy, A. (2005). Urban Informality: Toward an Epistemology of Planning. Journal of American Planning Association, 71(2), 147-58. https://doi.org/10.1080/01944360508976689

Roy, A. (2009). Strangely Familiar: Planning and the Worlds of Insurgence and Informality. Planning Theory, 8(1), 7-11. https://doi.org/10.1177/1473095208099294

Roy, A. (2011). Slumdog Cities: Rethinking Subaltern Urbanism. International Journal of Urban and Regional Research, 35(2), 223-238. https://doi.org/10.1111/j.1468-2427.2011.01051.x

Roy, A., \& AlSayyad, N. (2004). Urban Informality: Transnational Perspectives from the Middle East, Latin America, and South Asia. New York: Lexington.

Saad, O. A., Fikry, M. A., \& Hasan, A. E. (2019). Sustainable Upgrading for Informal Areas. Alexandria Engineering journal, 58(1), 237-249. https://doi.org/10.1016/j.aej.2019.03.001

Satterthwaite, D. (2011). Upgrading Dense Informal Settlements: The Potential for Health and Well-Being. Cities, Health and Well-Being. A Worldwide Investigation into the Future of Cities. Hong Kong.

Satterthwaite, D. (2016). Successful, Safe and Sustainable Cities: Towards a New Urban Agenda. Background Paper; Commonwealth Local Government Forum: London, UK. https://doi.org/10.5130/cjlg.v0i19.5446

Shen, L., Peng, Y., Zhang, X., \& Wu, Y. (2012). An Alternative Model for Evaluating Sustainable Urbanization. Cities, 29, 32-39. https://doi.org/10.1016/j.cities.2011.06.008

UNCHS (Habitat). (1997). Global Urban Observatory: Monitoring Human Settlements with Urban Indicators. Nairobi: UNCHS (Habitat).

UN-Habitat. (2003). The Challenge of Slums. Global Report on Human Settlements.

UN-Habitat. (2007). Global Report on Human Settlements 2007: Enhancing Urban Safety and Security. London: Earthscan.

UN-Habitat. (2008). State of the World's Cities 2010/2011: Bridging the Urban Divide. London: Earthscan Publications Ltd. https://doi.org/10.4324/9781849774864

UN-Habitat. (2012). Zambia Urban Housing Sector Profile. Housing Sector Profile Series. Shelter and Sustainable Human Settlements Development Division. UNON, Nairobi: Publishing Services Section.

UN-Habitat. (2014). The State of African Cities 2014: Re-imagining Sustainable Urban Transitions. Nairobi: United Nations Human Settlements Programme.

Yasini, M. (2007). A Report on the Status of Unplanned Settlements in Lusaka. Lusaka City Council. Research Unit. Lusaka.

Yin, R. (2003). Case Study Research: Design and Methods (3rd ed., Vol. 5, pp. 13). Thousand Oaks, CA: Sage Publication.

\section{Copyrights}

Copyright for this article is retained by the author(s), with first publication rights granted to the journal.

This is an open-access article distributed under the terms and conditions of the Creative Commons Attribution license (http://creativecommons.org/licenses/by/4.0/). 